\title{
Satellite tracking of two Montagu's Harriers (Circus pygargus): dual pathways during autumn migration
}

\author{
Christiane Trierweiler $\cdot$ Ben J. Koks $\cdot$ Rudi H. Drent $\cdot$ \\ Klaus-Michael Exo · Jan Komdeur · Cor Dijkstra • \\ Franz Bairlein
}

Received: 17 November 2006/Revised: 14 June 2007 / Accepted: 15 June 2007 / Published online: 19 July 2007

(C) Dt. Ornithologen-Gesellschaft e.V. 2007

\begin{abstract}
Autumn migration routes of two Dutch female Montagu's Harriers (Circus pygargus) were documented for the first time using satellite telemetry. Both migrated to their African wintering area-one via the Straits of Gibraltar through the Mediterranean and the other via Italy/ Tunisia. The rate of travel was comparable to values reported for larger raptor species.
\end{abstract}

Keywords Connectivity $\cdot$ Migration and food supply

\section{Introduction}

Satellite tracking has proven to be a useful technique to document migratory routes of large bird species, such as White Storks (Ciconia ciconia; Berthold et al. 1992, 2004), Peregrine falcons (Falco peregrinus; Fuller et al. 1998),

Communicated by A. Hedenström.

C. Trierweiler · B. J. Koks

Dutch Montagu's Harrier Foundation, PO Box 46,

9679 ZG Scheemda, The Netherlands

C. Trierweiler $(\bowtie) \cdot$ R. H. Drent $\cdot$ J. Komdeur

Animal Ecology Group, Centre for Ecological and Evolutionary

Studies, University of Groningen, PO Box 14, 9750 AA Haren,

The Netherlands

e-mail: C.Trierweiler@rug.nl

C. Trierweiler · K.-M. Exo · F. Bairlein

Institut für Vogelforschung "Vogelwarte Helgoland",

An der Vogelwarte 21, Wilhelmshaven 26386, Germany

C. Dijkstra

Behavioural Biology, University of Groningen, PO Box 14,

9750 AA Haren, The Netherlands
Ospreys (Pandion haliaetus; Hake et al. 2001; Alerstam et al. 2006) and eagle species (Meyburg et al. 1995, 2003). Western European Montagu's Harriers (Circus pygargus) winter in different West African countries (Fransson and Petterson 2001; Arroyo et al. 2004). During the autumn migration, the proportion of Harriers passing over Gibraltar is higher than that over Italy, but the reverse pattern is observed in spring. This has led to the hypothesis of loop migration: Harriers leaving Europe via Gibraltar and returning via Italy (Agostini and Logozzo 1997; Garcia and Arroyo 1998). In 2005, Montagu's Harriers could for the first time be tracked using satellite transmitters. Two Dutch female Harriers chose dual pathways during their autumn migration.

\section{Methods}

We used 12-g solar satellite transmitters (Microwave Telemetry, Columbia, Md.) that send signals for a 10-h period followed by a 48 -h pause. Data were obtained from the Argos system via CLS (Collecte Localisation Satellites, Toulouse, France). The satellite transmitters were attached on 16 July 2005 using teflon-ribbon backpacks (M. Gschweng, personal communication; Kenward 1987; Snyder et al. 1989). The total backpack weighed less than $5 \%$ of the females' body weight. Hereafter, we refer to the first female as Marion and the second female as Beatriz. Both females successfully bred in 2005 in the northeastern part of The Netherlands (Marion: four fledglings, Beatriz: two). Based on iris colouration observed in 2005 and before (Arroyo et al. 2004), Marion was assessed as being at least in her fifth calender year and Beatriz at least her third. STAT and MAPTOOL software were used for analyses (Coyne and Godley 2005). Only high-quality fixes with a 
presumed error between $150 \mathrm{~m}$ and several kilometres (CLS) were included.

\section{Results and discussion}

The two Montagu's Harriers used a western and a central route, respectively, through the Mediterranean during the autumn migration (Fig. 1). Marion's stay at her wintering site in Nigeria ended when she was killed by a local farmer (20 November), at which time she had been tracked for almost $5000 \mathrm{~km}$. Beatriz' transmitter failed, after almost $3000 \mathrm{~km}$ of tracking, in Morocco (25 September). The fact that Marion left just 2 days after Beatriz may have been caused by the influence of large-scale weather systems. Both females left ahead of their mates (Marion: at least

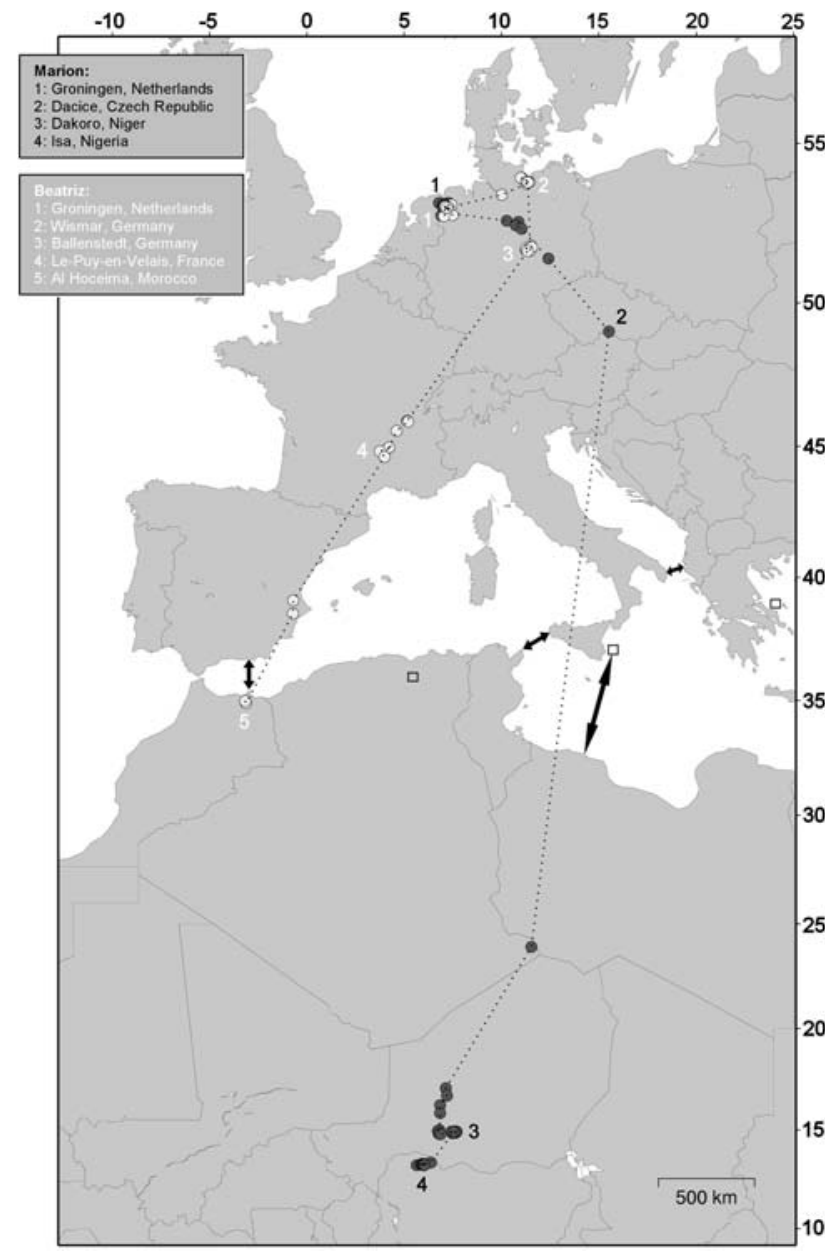

Fig. 1 Migratory routes of two satellite-tracked Montagu's Harrier females in 2005 (dotted lines). Circles represent fixes, numbers represent staging areas (black Marion, white Beatriz; see Fig. 2). The three fixes that are not included in Marion's migratory route represent the low-quality locations in Italy with its mirror image in Greece (8 September) and in Algeria (11 September). Arrows indicate the minimum distances the Harriers had to fly over the sea
11 days, Beatriz: no precise estimate available). Marion left The Netherlands in a southeastern direction, crossing breeding areas of neighbouring German harrier populations (rate of travel: 56-114 $\mathrm{km} \mathrm{day}^{-1}$ ) (Fig. 2). Beatriz left in a northeastern direction $\left(80 \mathrm{~km} \mathrm{day}^{-1}\right)$. After two stop-overs in Germany, Beatriz continued to south-central France (LePuy-en-Velay, Haute-Loire, $190 \mathrm{~km} \mathrm{day}^{-1}$ ) and stayed 7 days in this part of the French Montagu's Harrier breeding range (Millon et al. 2004) (Fig. 2). A possible explanation for the initial movements in easterly directions is the visiting of neighbouring Montagu's Harrier breeding areas and "prospecting" for future breeding sites. Hake et al. (2001) reported that a female Osprey bred at her first autumn migration stop-over site in the following year. It is also possible that the females originated from more Eastern populations and visited their native sites, which has also been observed in the Osprey (Hake et al. 2001). Whether the choice of migratory route is mainly based on contemporary cues (weather, food abundance, body condition) or on the past origin and inherited traits of the birds remains open.

Both females seemed to choose relatively narrow sea crossings near Gibraltar and Italy, respectively. Beatriz may have crossed the Mediterranean East of Gibraltar (140 km over the open sea; Fig. 1), as 65\% of Montagu's Harriers migrating through this region do crosse here (Meyer et al. 2000). High-quality fixes of Marion between the Czech Republic and Niger were lacking. A low-quality fix of 8 September indicated a position in Italy, with its mirror image in Greece (Fig. 1). A low-quality fix in Algeria (11 September) suggests that Marion took the route via Italy. To reach Italy via the Adriatic Sea required at least a $80-\mathrm{km}$ flight over the open sea. Taking the location in Algeria into account, we assume that Marion did not fly

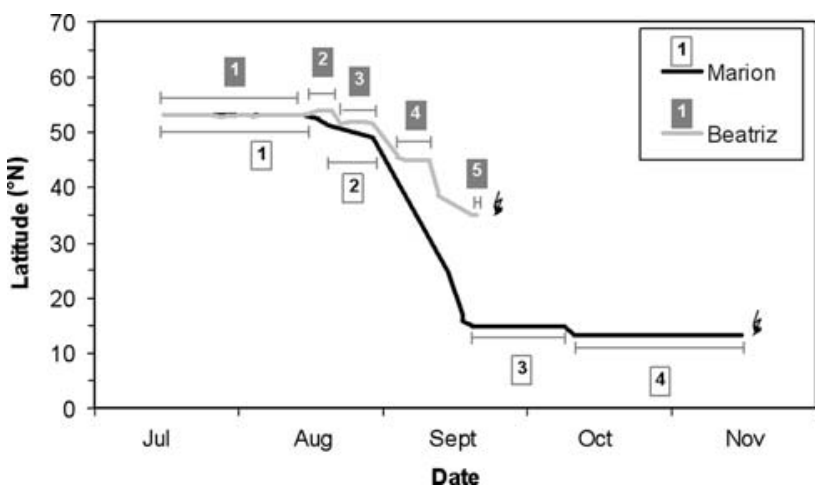

Fig. 2 Timing of autumn migration of two Montagu's Harrier females. Numbers indicate staging or stop-over areas, corresponding to Fig. 1. Marion: 1 Groningen, The Netherlands, 2 Dacice, Czech Republic, 3 Dakoro, Niger, 4 Isa, Nigeria. Beatriz: 1 Groningen, The Netherlands, 2 Wismar, Germany, 3 Ballenstedt, Germany, 4 Le-Puyen-Velay, France, 5 Al Hoceima, Morocco. Scale bars indicate length of stay, lightning bolt indicates transmitter failure 
the $480 \mathrm{~km}$ from Italy to Libya but arrived in Tunisia first, which means a $140-\mathrm{km}$ sea crossing.

Based on studies on the Peregrine falcon and Osprey, it is known that migration is faster in the middle phase than in the beginning and at the end (Fuller et al. 1998; Kjellén et al. 2001). We observed the same seasonal pattern in terms of daily distances covered for the two Harriers: whereas in August they covered maximally just above $100 \mathrm{~km} \mathrm{day}^{-1}$, the distances became longer in the first half of September. Marion reached her highest rate of travel above the Sahara, as has been found for Ospreys (Kjellén et al. 2001), when she travelled up to $623 \mathrm{~km} \mathrm{day}^{-1}$ (1247 km on 16-17 September) before slowing down before she reached her first destination, Dakoro (Niger) on 21 September. Assuming a straight travel route and a constant rate of travel between Italy and Niger, crossing the Sahara would have taken her 8 days. The average daily distance Marion covered on travel days was $168 \mathrm{~km}$. The average over both travel and stop-over days during the migration period was $143 \mathrm{~km} \mathrm{day}^{-1}$. If we assume that the lowquality fixes in Italy and Algeria were correct, this travel rate would have been $160 \mathrm{~km}$. Both estimates are similar to those found for heavier raptor species, such as the Greater Spotted Eagle (Aquila clanga; $150 \mathrm{~km} \mathrm{day}^{-1}$; Meyburg and Meyburg 1999), Lesser Spotted Eagle (Aquila pomarina; $166 \mathrm{~km} \mathrm{day}{ }^{-1}$; Meyburg and Meyburg 1999), Peregrine falcon (172 $\mathrm{km} \mathrm{day}^{-1}$; Fuller et al. 1998) and Osprey (183 km day ${ }^{-1}$; Alerstam et al. 2006). Marion's maximum daily distance of $623 \mathrm{~km}$ was again similar to the $537 \mathrm{~km} \mathrm{day}^{-1}$ reported for the Lesser Spotted Eagle (Meyburg and Meyburg 1999). Taking this into account, it seems likely that Montagu's Harriers are able to migrate at similar rates of travel as the larger and heavier raptors.

Marion apparently did not engage in loop migration (at least not in the predicted direction), and this behaviour could not be evaluated for Beatriz due to the early lack of signals. The exact proportions of Western European Montagu's Harriers that use the western or central route through the Mediterranean and the extent of migratory connectivity between different breeding and wintering areas will have to be investigated using larger sample sizes of tracked birds and ring recoveries.

\section{Zusammenfassung}

Satellitentelemetrische Studie von zwei Wiesenweihen (Circus pygargys): unterschiedliche Routen auf dem Herbstzug

Der Herbstzug zweier niederländischer Wiesenweihenweibchen wurde zum ersten Mal mittels Satellitentelemetrie dokumentiert. Einer der Vögel zog über Gibraltar durch das Mittelmeergebiet, der andere zog über Italien/ Tunesien in das afrikanische Überwinterungsgebiet. Tagesetappen waren vergleichbar mit Werten, die für größere Greifvögel dokumentiert sind.

Acknowledgements Erik Visser and Marion Gschweng helped attach the transmitters. Michael Coyne, Mark Fuller, Kurt Burnham, Roy Dennis, Götz Eichhorn and Joost Brouwer provided valuable advice. Ringing licences were obtained from the Dutch Bird Ringing Centre. STAT and Maptool software were obtained from http:// www.seaturtle.org. The Nederlandse Aardolie Maatschappij and AKZO-Nobel sponsored the purchase of the satellite transmitters. The Ministry of Agriculture, Nature and Food quality, the Province of Groningen, the Prince Bernhard Cultural Foundation and Vogelbescherming Nederland (BirdLife Netherlands) provided financial support. This study complies with the current laws of the Netherlands and it was approved by the Institutional Animal Care and Use Committee of the University of Groningen under licence number D4382B.

\section{References}

Agostini N, Logozzo D (1997) Autumn migration of Accipitriformes through Italy en route to Africa. Avocetta 21:174-179

Alerstam T, Hake M, Kjellén N (2006) Temporal and spatial patterns of repeated migratory journeys by Ospreys. Anim Behav 71:555-566

Arroyo BE, García JT, Bretagnolle V (2004) Circus pygargus Montagu's Harrier. BWP Update 6:41-55

Berthold P, Nowak E, Querner U (1992) Satelliten-Telemetrie beim Weißstorch (Ciconia ciconia) auf dem Wegzug - eine Pilotstudie. J Ornithol 133:155-163

Berthold P, Kaatz M, Querner U (2004) Long-term satellite tracking of white stork (Ciconia ciconia) migration: constancy versus variability. J Ornithol 145:356-359

Coyne MS, Godley BJ (2005) Satellite tracking and analysis tool (STAT): an integrated system for archiving, analyzing and mapping animal tracking data. Mar Ecol-Prog Ser 301:1-7

Fransson T, Petterson J (2001) Svensk ringmärkningsatlas. vol 1. Naturhistoriska Riksmuseet and Sveriges Ornitologiska Förening, Stockholm

Fuller MR, Seegar WS, Schueck LS (1998) Routes and travel rates of migrating Peregrine Falcons Falco peregrinus and Swainson's Hawks Buteo swainsoni in the Western Hemisphere. J Avian Biol 29:433-440

García JT, Arroyo BE (1998) Migratory movements of western European Montagu's Harrier Circus pygargus: a review. Bird Study 45:188-194

Hake M, Kjellén N, Alerstam T (2001) Satellite tracking of Swedish Ospreys Pandion haliaetus: autumn migration routes and orientation. J Avian Biol 32:47-56

Kenward R (1987) Wildlife radio tagging. Academic, London

Kjellén N, Hake M, Alerstam T (2001) Timing and speed of migration in male, female and juvenile Ospreys Pandion haliaetus between Sweden and Africa as revealed by field observations, radar and satellite tracking. J Avian Biol 32:5767

Meyburg B-U, Meyburg C (1999) S49.2: The study of raptor migration in the Old World using satellite telemetry. In: Adams NJ, Slotow RH (eds) Proc 22 Int Ornithol Congr Durban. BirdLife South Africa, Johannesburg, pp 2992-3006

Meyburg B-U, Scheller W, Meyburg C (1995) Zug und Überwinterung des Schreiadlers Aquila pomarina: Satellitentelemetrische Untersuchungen. J Ornithol 136:401-422 
Meyburg B-U, Paillat P, Meyburg C (2003) Migration routes of Steppe Eagles between Asia and Africa: a study by means of satellite telemetry. Condor 105:219-227

Meyer SK, Spaar R, Bruderer B (2000) To cross the sea or to follow the coast? Flight directions and behaviour of migrating raptors approaching the Mediterranean sea in autumn. Behaviour 137:379-399
Millon A, Bretagnolle V, Leroux A (2004) Busard cendré Circus pygargus. In: Thiollay J-M, Bretagnolle V (eds) Rapaces nicheurs de France, distribution, effectifs et conservation. Delachaux et Niestlé, Paris, pp 70-74

Snyder NFR, Beissinger SR, Fuller MR (1989) Solar radio-transmitters on snail kites in Florida. J Field Ornithol 60:171-177 